\title{
The verification of educational objectives in the chemistry education of the Czech Republic
}

\author{
Jan Tř́ska ${ }^{1 a}$, and Hana Čtrnáctová ${ }^{1}$ \\ ${ }^{1}$ Charles University, Faculty of Science, Department of Teaching and Didactics of Chemistry, \\ Albertov 6, 128 42, Prague, Czech Republic
}

\begin{abstract}
The educational objectives in the Czech Republic are determined by so-called Framework Education Programs. For each individual subject, compulsory curriculum and expected outcomes of pupils are determined. Expected outcomes are defined by active verbs and they match the highest level of Bloom's taxonomy of educational objectives. For the pupils to reach these objectives, they first have to acquire the knowledge and skills of the lower levels. Our project is focused on the creation of indicators, by which we mean suitable learning exercises, which serve to verify the attainment of objectives of chemistry education at upper secondary school. These indicators are being created on the three levels of difficulty - acquisition of knowledge, the application of said knowledge, and reasoning and problem solving. The indicators are being tested in the school practice.
\end{abstract}

Keywords: Educational objectives; curriculum; Czech Republic

\section{Introduction}

In the year 2000, the preparations of the reform of the school system started in the Czech Republic. In 2004, they resulted in the introduction of the so-called Framework Educational Program on the level of preschool, primary, secondary school and higher vocational school. Since 2004 the school reform has been in progress. This project is focused on students between 15 and 18 years who study at upper secondary school. In the Czech Republic, this type of general education school is called "Gymnasium." The Framework Educational Program for gymnasiums [1] defines the educational objectives and reflects needs and trends in education of the $21^{\text {st }}$ century [2]. In the scope of school's individual subjects, the subject of chemistry among them, the Framework Educational Program for gymnasiums defines the compulsory content of curriculum and the cognitive objectives. The educational objective is expressed by so-called expected outcomes of the student and these expected outcomes are defined by active verbs.

\footnotetext{
a Corresponding author: triskaja@gmail.com
} 


\subsection{The drawbacks of Framework Educational Programs}

A certain trend, which was brought by the Framework Educational Program, is a departure from the cognitive objectives. However, the authors of this project are of opinion that the cognitive objectives occupy an irreplaceable spot in the secondary school education (gymnasium) and this reduction of the curriculum documents prevents the evaluation of the success in the education. The Framework Educational Program for the gymnasium mentions only 4 general cognitive objectives for the general chemistry:

- Student uses technical terminology for describing substances and explaining chemical processes,

- Student performs chemical calculations and applies them to solving practical problems,

- Student predicts the properties of elements and their behavior in chemical processes based on the knowledge of the Periodic System of Elements,

- Student uses knowledge of the particle structure of substances and chemical bonds to predict some physico-chemical properties of substances and their behavior in chemical reactions.

These objectives match the highest level of the Bloom's taxonomy of educational objectives [3] and they are introduced by words such as "predicts, applies, and uses the knowledge for prediction". We assume that the student will reach these levels only after acquiring the knowledge and skills on the lower levels of the Bloom's taxonomy of educational objectives. We also think that the existence of a greater number of the cognitive objectives and tools for their verification will provide us with relevant data about the success of chemistry education at the upper secondary school. Currently, no such tools for the verification of the educational objectives at the gymnasium exist.

\section{Methods}

Our project is focused on the creation of the indicators, suitable learning tasks, which will test the attainment of the cognitive objectives of the chemistry education at the gymnasium [4]. Among other things, testing of 15 to 18 years old aged students is missing in the Czech Republic. The goal of the project is to prepare a set of indicators, which will reliably verify these objectives of general chemistry written in the Framework Educational Program.

\subsection{Indicators of chemical education}

An indicator is an observable fact which indicates the presence of unobservable fact [5]. Indicators are usually used for monitoring and controlling [6]. At school, we want to evaluate and verify educational results. Educational indicators are qualitative indicators that tell us about the characteristics, functioning and financing of the education system [7]. In curriculum, it is expected that students achieve certain objectives. As soon as we define the expected outcomes, we should say how to verify them. One way of verifying the expected outcomes of students is the creation of the indicators of the educational results. Learning tasks are good indicators for evaluating the quality of education [8]. The Created learning tasks validate various levels of subject matter and achievement of the expected outcomes of students.

\subsection{Three levels of indicators}

The indicators are created for three levels of difficulty - acquisition of knowledge, application of the said knowledge and reasoning and problem solving. The creation of 
indicators had been preceded by assessment of the similar objectives for the general chemistry. The recourse was an analysis of the documents, especially of the catalogue of requirements for the common part of the school-leaving chemistry exam [9]. If the suitable objective wasn't present in the catalogue, it was designed by the authors of this project. The created indicators are being consulted with focus group, who are able ascertain the suitability of the established objectives.

\subsection{Example of designed indicator}

Here is an example of a designed indicator (Fig. 1). The set is focused on phenomenon of radioactivity. The first tasks is about using radioactivity in medicine, especially in the spa treatment. The exercise is focused on the acquisition of knowledge and the expected outcomes of students are:

- The student describes the types of radioactive radiation and defines the differences between natural and artificial radioactive transformation of elements.

- The student describes the types of nuclear reactions and writes the equations of nuclear reactions in accordance with the weight conservation law.

\section{Radioactive treatment in Jáchymov}

In the Ore Mountains lies the town of Jáchymov, famous for its uranium mines and spa (Task fig. 1). For the treatment of diseases of the locomotoric system, peripheral nerves and vessels, radon water containing radon isotopes ${ }_{{ }_{\mathrm{G}}}^{222} \mathrm{Rn} n$ is used. The ionizing radiation that radon water produces has stimulating effects on the body. Radon isotope ${ }^{22} \mathrm{ke} R \mathrm{Rn}$ is transformed

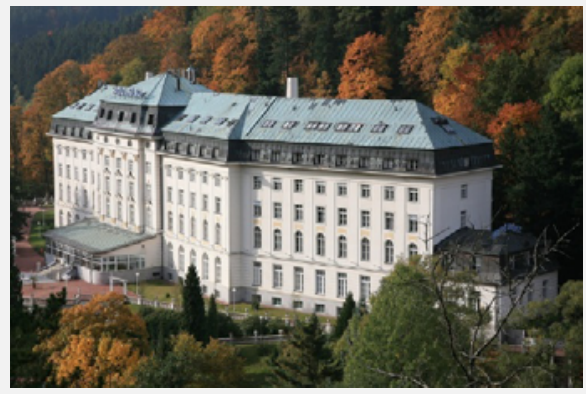

Task fig. 1 - Spa in Jáchymov, Czech Republic into the polonium isotope ${ }_{94}^{219} \mathrm{Po}$ during the radioactive conversion:

$$
{ }_{86}^{222} \mathrm{Rn} \rightarrow{ }_{94}^{219} \mathrm{Po}+
$$

Fig. 1a: The preview of indicator for the lowest level of acquisition 


\section{Question 1:}

Which particles generate ionizing radiation?
a) Hydrogen isotope nuclei ${ }_{1}^{1} \mathrm{H}$
b) Helium isotope nuclei ${ }_{2}^{4} \mathrm{He}$

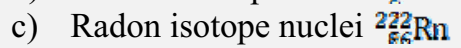
d) Polonium isotope nuclei ${ }_{84}^{218} \mathrm{Po}$

\section{Question 2:}

This type of ionizing radiation, which is the least penetrating and has the least energy, is also denoted by the Greek letter. What kind of radioactive radiation is it?
a) $\alpha$-radiation
b) $\beta^{-}$-radiation
c) $\beta^{+}$-radiation
d) $\mathrm{y}$-radiation

Fig. 1b: The preview of indicator for the lowest level of acquisition

The task on the second level of the Bloom's taxonomy (the application of the said knowledge) is focused on thermonuclear fusion on the surface of the sun. The preview is shown in the fig. 2. The task on the highest level (reasoning and problem solving) is focused on the application of radioactivity in nuclear power engineering and the preview is shown in the fig. 3 . We try to ensure that all indicators are applied to practical examples.

\section{What is happening in the Sun?}

The Sun is a star which is situated in the center of the Solar System. It is composed of hot plasma and constantly produces a tremendous amount of energy. This energy is generated in the Sun through thermonuclear reactions that have been, and still are, the basic prerequisite for life on Earth. The Sun supplies Earth with light and warmth.

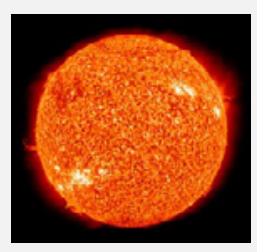

\section{Task fig. 2 - The Sun}

\section{Question:}

Sun's energy is produced by a particular thermonuclear reaction - so-called thermonuclear fusion. Which of the following reactions is an example of thermonuclear fusion that is consistent with the mass conservation law?
a) ${ }_{1}^{2} \mathrm{H}+{ }_{1}^{3} \mathrm{H} \rightarrow{ }_{2}^{4} \mathrm{He}$
b) ${ }_{1}^{2} \mathrm{H}+{ }_{1}^{3} \mathrm{H} \rightarrow{ }_{2}^{4} \mathrm{He}+{ }_{\mathrm{n}}^{1} \mathrm{n}$
c) ${ }_{2}^{4} \mathrm{He}+{ }_{0}^{1} \mathrm{n} \rightarrow{ }_{1}^{2} \mathrm{H}+{ }_{1}^{3} \mathrm{H}$
d) ${ }_{23.5}^{235} \rightarrow{ }_{2}^{4} \mathrm{He}+{ }_{\%_{\mathrm{O}}}^{231} \mathrm{Th}$

Fig 2: The preview of indicator for the medium level of acquisition 
How does the nuclear power station work?

Nuclear power stations (Task fig. 3) produce energy through a steam turbine that drives alternators to produce electricity. The steam is generated by evaporation of the liquid water in the steam generator. The heat that is needed for this transformation is a fissionable nuclear reaction. The basic type of fuel is uranium ore containing isotope ${ }_{92}^{235} \mathrm{U}$.

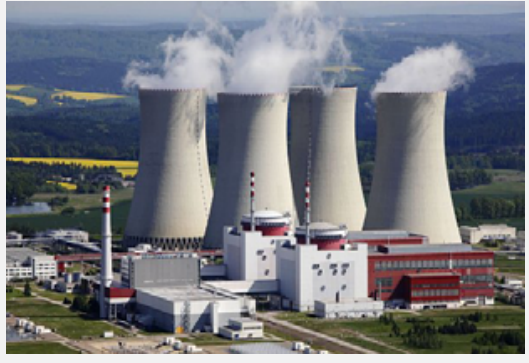

Task fig.3 - Nuclear power station Temelín, Czech Republic

\section{Question:}

The fission nuclear reaction that takes place in a nuclear reactor is schematically shown in the Task fig. 4. This reaction is initiated by neutrons which bombard uranium isotope ${ }_{9}^{235} \mathrm{U}$.

Describe the next course of this fission reaction in your own words:

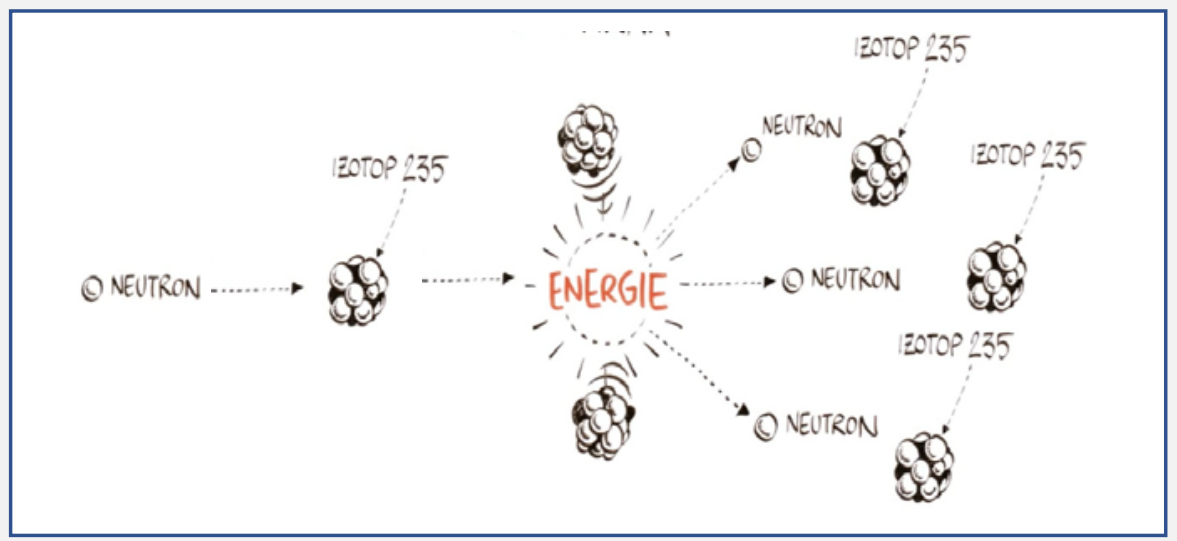

Task fig. 4 - Nuclear reaction in nuclear reactor

Fig. 3: The preview of indicator for the highest level of acquisition

The tasks are always followed by methodical comments. There we note the correct solutions and how the task should be evaluated. In the methodical comments, we also explain what part of the curriculum is verified by this task, and on what level (Fig. 4). 


\section{Methodical comments and evaluation of the task}

The goal of the first task is to demonstrate the student's knowledge of radioactivity. From the task assignment, it is likely that the isotope of radon ${ }_{86}^{222} \mathrm{Rn}$ is transformed into the polonium ${ }_{84}^{218} \mathrm{Po}$ isotope, which releases radioactive radiation. In the second part of the task, the student demonstrates further knowledge of a fact that the helium helix current is also called $\alpha$-radiation.

Correct solution: $1 \mathrm{~b}) ; 2$ a)

The goal of the second task is to verify whether the student can apply this knowledge and correctly write the equation of a thermonuclear reaction based on its description. At the same time, they have to determine the proper reactants and reaction products (i.e. hydrogen isotopes), and also take into account the mass conservation law.

Correct solution: b)

The goal of the third task is to show the student's ability of reasoning and problem solving on an example of a practical application of nuclear reactions in nuclear power plants. The schematics of reaction should allow the student to determine and describe in their own words how the reaction will continue.

Correct solution: The nuclear reaction is caused by a neutron that causes the nucleus of uranium isotope 235 to split. This results in two lighter nuclei and the release of three more neutrons. These neutrons cause the fission of more nuclei, which causes the reaction to continue on its own with increasing speed. Because of that, the power plants must control the reaction and capture excess neutrons in order to prevent a runaway reaction and explosion.

Fig. 4: Methodical comments and evaluation of the tasks

\section{Results}

We are currently finishing the design of indicators. We have designed 10 sets of indicators on different topics from general chemistry: Substances and Their Properties, Calculation from Chemical Equations, Solutions, Atomic Electron Shell, Radioactivity, Chemical Bonds, Thermochemistry, Speed of Chemical Reactions, Acid-base Processes, and Redox Processes. In 2018, we are going to verify the indicators in practice. Students who will solve the sets of indicator tasks will be rated according to their success and according to the input data, which they have provided to the reviewers. The input data will be obtained from a questionnaire, where we will focus on the understanding of the topics, the student's motivation, readiness, and self-confidence during problem solving. The results of our project will allow the establishing of more detailed cognitive objectives for curriculum of general chemistry at gymnasiums and the use of the designed tools - indicators - for the verifications of these objectives within the chemistry education in the Czech Republic. Suboutcomes of the project will be data about the attitude of Czech students toward learning and solving tasks - which is 2 of the 6 key competencies defined by the Framework Educational Programs. The designed indicators, which will be verified on the sample of Czech students and evaluated by experts, will be further provided to other institutions, both domestic and foreign.

\section{Discussion and conclusion}

According to the Framework Educational Program, the students should achieve the highest level of educational objectives. However, we expect the reality to be different. We are 
going to test these students at their schools, after the teacher finishes their explanation of the topic. We suppose that the largest group of the students will be able to solve only the lowest level of indicators correctly. We also expect, that only very few students will be able to solve the highest level of the indicators, although it is compulsory according to the Framework Educational Program. This should prove that the current state of the Framework Educational Program was badly designed and it is not useful in practice. In our opinion, the Framework Educational Program should be remade to be more specific and it should include more cognitive objectives including the objectives of the lower levels of Bloom's taxonomy. We hope that our project will prove there is a need for these changes.

The main benefit of our project is that the designed indicators can be useful for gymnasium teachers. They will have the indicators available, accompanied by a list of expected student outcomes. The teachers can assign these indicators to their students and evaluate the results [10]. Based on the evaluation of the indicator, the teachers will be able to give feedback to their students and they can help them with improving their results in the future.

\section{References}

1. MŠMT (2007) Rámcový vzdělávací program pro gymnázia (RVP G). Praha: Výzkumný ústav pedagogický v Praze. ISBN 978-80-87000-11-3.

2. Delors, J. (1998). Learning: The treasure within - report to UNESCO of the International Commission.Paris : UNESCO

3. Anderson, L., W.; Krathwohl, D., R., eds. (2001). A taxonomy for learning, teaching, and assessing: A revision of Bloom's taxonomy of educational objectives. Allyn and Bacon.

4. Tř́íska, J., Čtrnáctová, H. (2016). Indicators of Educational Results in Chemistry Teaching. Proceedings of the 7th International Conference on Research in Didactics of the Sciences DidSci 2016, Kraków, Poland. ISBN 978-83-8084-037-9.

5. Bunge, M. (2003) Philosophical Dictionary, Enlarged Edition. New York: Prometheus Books. ISBN 1-59102-037-9.

6. Janoušková, S., Maršák, J. (2008). Indikátory - významný prostředek našeho poznávání. Pedagogika, 52 (1),s. 29-35.

7. Průcha, J., Walterová, E., Mareš, J. (2009) Pedagogický slovník. 6. rozšířené a aktualizované vydání. Praha: Portál, 395 s. ISBN 978-807-3676-476.

8. Čtrnáctová, H. (2009). Učební úlohy v chemii 1. díl. (2. vyd.) Praha, Karolinum.

9. MŠMT (2004) Katalog požadavkủ ke společné části maturitní zkoušky v roce 2004: Chemie. Praha: CERMAT.

10. Straková, J. (2013). Jak dál s kurikulární reformou. Pedagogická orientace, roč. 23, č. 5, s. 734-743. 